ZOOLOGIA 31 (5): 418-425, October, 2014

http://dx.doi.org/10.1590/S1984-46702014000500002

\title{
Autoecology of Dryadosaura nordestina (Squamata: Gymnophthalmidae) from Atlantic forest fragments in Northeastern Brazil
}

\author{
Adrian A. Garda ${ }^{1, *}$, Pedro H.S. de Medeiros ${ }^{1}$, Marília B. Lion' ${ }^{1}$, Marcos R.M. de Brito ${ }^{1}$, \\ Gustavo H.C. Vieira² \& Daniel O. Mesquita²
}

\author{
1 Laboratório de Anfíbios e Répteis, Departamento de Botânica e Zoologia, Centro de Biociências, Universidade Federal do Rio \\ Grande do Norte. Campus Universitário, Lagoa Nova, 59078-970 Natal, RN, Brazil. \\ 2 Departamento de Sistemática e Ecologia, Centro de Ciências Exatas e da Natureza, Universidade Federal da Paraíba. \\ 58051-900 João Pessoa, PB, Brazil. \\ *Corresponding author. E-mail: pseudis@gmail.com
}

\begin{abstract}
Life history parameters such as diet, reproduction, and sexual dimorphism are crucial to understand ecological and evolutionary forces shaping species traits. Nevertheless, such information is scant in the literature for most Neotropical squamates. Gymnophthalmidae contains over 242 species in 46 genera and includes small-size, mostly terrestrial species, although psamophilic, semi-aquatic, and low vegetation dwellers also occur. Dryadosaura is a monospecific genus - Dryadosaura nordestina Rodrigues et al., 2005 -, occurring in Atlantic Forest areas from Rio Grande do Norte to Northern Bahia, and little is known about its ecology and natural history. We analyzed the species' diet, reproduction, and sexual dimorphism based on 170 specimens deposited in museum collections. Dryadosaura nordestina is considered generalist and active forager, based on dietary items. Arthropods, especially ants and insect larvae, dominate the diet. The reproductive period shows a peak during the rainy season (May through June), while recruitment occurs from July through November. Males are significantly larger than females, and sexes can also be distinguished based on shape variables: males have higher heads and longer bodies, while body height and width are larger in females.
\end{abstract}

KEY WORDS. Diet; ecology; lizard; reproduction; sexual dimorphism.

Autoecological parameters such as diet, age at maturity, reproduction, and sexual dimorphism are crucial to understand the ecology and natural history of species (Stearns 1992, VitT 2013). Diet is determined by species ecological characteristics through the energetic gain provided by feeding, and also by historical factors (Doughty 1997, VitT \& Pianka 2005, VitT et al. 2007b). Reproduction involves complex tradeoffs between fecundity and energy costs evidenced, for example, by variations in clutch (or litter) size and number of clutches in the same species (Vitt \& Congdon 1978, Pianka \& VitT 2003). The study of life history parameters is crucial to understand key ecological and evolutionary forces determining and constraining the existence of each species (Dunham et al. 1988).

Squamates include over 9,700 species of amphisbaenids, lizards, and snakes that range from animals as small as $3 \mathrm{~cm}$ to over several meters long (Pianka \& VitT 2003). Over 80\% of the species are small body vertebrates (less than 20 grams). Their diet is mostly based on invertebrates, and their reproduction can be oviparous, viviparous, or parthenogenic (PIANKA \& VITT 2003). Lizards have been important model organisms to study the evolution of ecological and morphological traits (VITT \& PIANKA
2005, Losos 2009), but conflicts between molecular and morphological phylogenies have cast doubt on some of the traditional hypotheses of trait evolution in the group (Losos et al. 2012, Pyron \& Burbrink 2014). Not less important, the lack of natural history data for most species (especially in the tropics) still hampers the appropriate testing and formulation of evolutionary hypotheses. Indeed, only 5\% of squamate species have been adequately studied for their natural history traits (VITT 2013).

Gymnophthalmidae harbors over 242 lizard species in 46 genera, restricted to the new world from Southern Mexico to Central Argentina (Vitt \& Caldwell 2013). They are small to medium sized lizards that may be fossorial, psamophilic, terrestrial, or aquatic, but most of them live in the leaf litter or perched on low branches of the vegetation (Pellegrino et al. 2001, CASTOE et al. 2004). They present several adaptations to fossorial and semi-fossorial life, such as reduced limbs, elongated bodies, loss of external ear opening and eyelids (BARRos et al. 2011, GrizAnTE et al. 2012). In Brazil there are 84 Gymnophthalmidae species distributed in 32 genera. Dryadosaura is a monospecific genus occurring in the Northeastern part of the Brazilian Atlantic Forest, from Rio Grande do Norte to Bahia (Rodrigues et al. 2005, САMACHO 
\& Rodrigues 2007, Delfino \& Soeiro 2012, de Oliveira \& Pessanha 2013). Dryadosaura nordestina Rodrigues et al., 2005 is characterized by individuals with short limbs and robust bodies (Fig. 1).

Little is known about the ecology and natural history of D. nordestina, a species until recently poorly represented in herpetological collections. Moreover, there is no data available on reproduction and sexual dimorphism of the species, and dietary information is scarce and based on small sample sizes (U.G. Silva, unpubl. data). Such data is important not only for the general understanding of the species' ecology, but also for its conservation and management. Based on a sample of 170 specimens we analyzed the species diet, sexual size and shape dimorphism, and reproduction.

\section{MATERIAL AND METHODS}

We used 170 specimens (120 males and 50 females) housed in the Coleção do Laboratório de Anfíbios e Répteis da Universidade Federal do Rio Grande do Norte (CLAR-UFRN) and Coleção Herpetológica da Universidade Federal da Paraíba (CHUFPB). All individuals were collected inside Atlantic Forest fragments in the states of Rio Grande do Norte and Paraíba. Specimens were collected in Rio Grande do Norte with scientific collecting permit issued by ICMBio (19828-4) and an animal use and care committee approved protocol (CEUA UFRN 017/2011). Specimens from Paraíba were collected by other researchers and were loaned for the present study.

We analyzed stomach contents of 106 individuals. Specimens were dissected and stomachs removed and stored in ethanol 70\%. We identified preys to the lower taxonomic category possible (usually order) in a stereomicroscope. Volume of prey items was estimated using the formula of volume for an ellipsoid: $V=3 / 4 \pi\left(\right.$ Length/2)(Width/2) ${ }^{2}$.
For each prey category we calculated frequency, numeric and volumetric percentage and an importance index based on individual stomachs, IIS (N\%+V\%)/2, and on pooled stomachs, IPS $(\mathrm{F} \%+\mathrm{N} \%+\mathrm{V} \%) / 3$.

Sex and reproductive status were determined through the dissection and direct observation of gonads. We measured width and length of testis in males and of all eggs and follicles found in females. Males were considered sexually mature when enlarged testes and convoluted epididymis were observed. Female reproductive condition was ranked as follows: 1) non reproductive, females with undeveloped ovarian follicles with no difference in size among them; 2) Stage I: differentiated follicles with slightly convoluted oviduct; 3) Stage II: well developed ovarian follicles, developed oviducts, but no eggs present; 4) Stage III: eggs in the oviduct. Size at maturity was estimated based on the smallest male and females (stage I) considered reproductive.

For morphometric analyses we measured 10 variables with a digital caliper to the nearest $0.01 \mathrm{~mm}$ : snout-vent length (svl), tail length (tl), tail base length (tb), body length (bl) and width (bw), head width (hw), length (hl), and height (hh), forelimb length (fl), and hindlimb length (hll). We used adaptive outlier detection with package mvoutlier (FILzMoser et al. 2005) in R v. 3.0.2 (R Development Core Team 2013) to screen the data for multivariate outliers. Six females (14\%) and 14 males (12\%) were removed from the analyses after being detected as multivariate outliers.

To partition the morphometric variation into size and shape, we defined Body Size as a variable resulting from the multiplication of an isometric vector, with values of $\mathrm{p}^{-0.5}$ (where $\mathrm{p}$ is the number of variables) by the $\mathrm{n} \mathrm{x}$ p matrix of $\log _{10}$ transformed morphometric data, where $\mathrm{n}$ is the number of observations (Jolicoeur 1963, Somers 1986, Rohlf \& Bookstein 1987). To

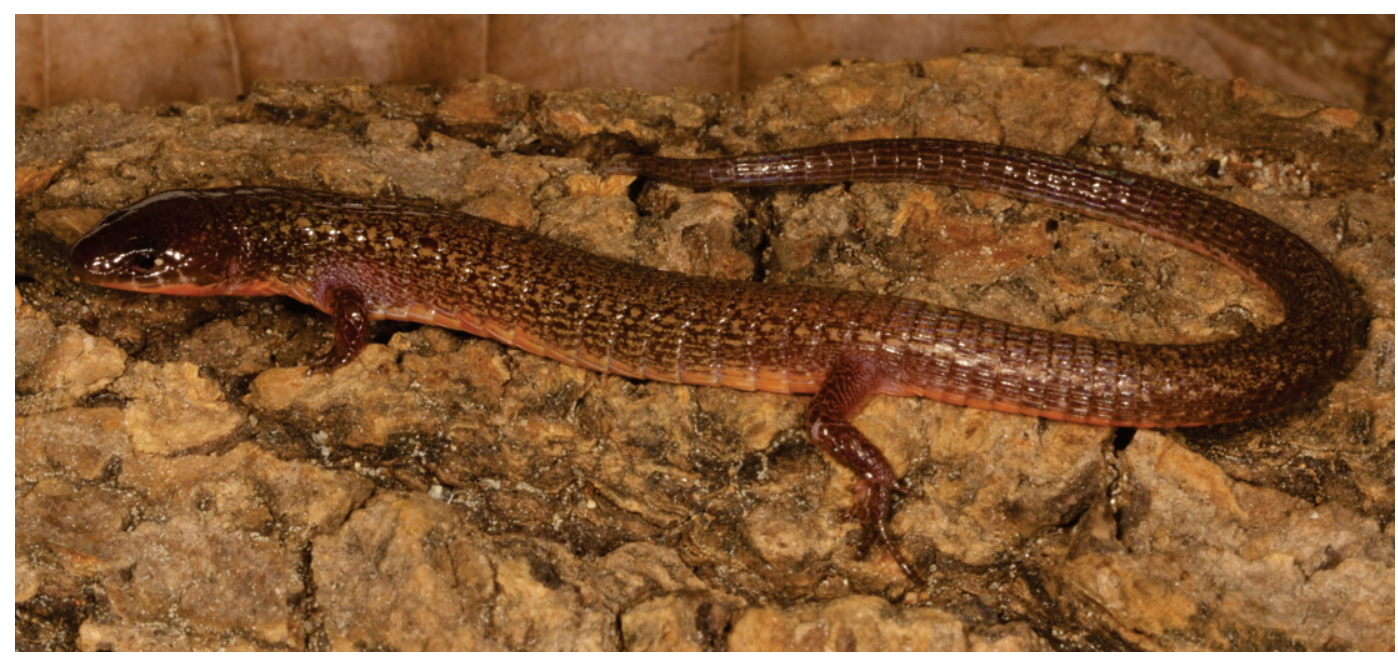

Figure 1. Adult male Dryadosaura nordestina collected in an Atlantic Forest fragment from southeastern Rio Grande do Norte State, Brazil. 
remove the effect of size of the $\log _{10}$ transformed variables we used the method described by Burnaby (1966), where the $n \times p$ matrix of log transformed data is multiplied by a symmetric matrix, $L$, defined by: $L=I_{p}-V\left(V^{\top} V\right)^{-1} V^{\top}$, where $I_{p}$ is a p x p identity matrix, $\mathrm{V}$ is the isometric size eigenvector defined above, and $\mathrm{V}^{\mathrm{T}}$ is the transpose of matrix $\mathrm{V}$ (RohlF \& BooksteIn 1987). The resulting variables represent Shape Variables.

To evaluate differences between sexes, we conducted an ANOVA on Body Size and used a logistic regression on Shape Variables (TABACHNICK \& Fidell 2001). We compared the full model against a constant-only (null) model using a chi-square test of the scaled deviance to evaluate the statistical significance of the full model based on shape variables (Сhambers \& Hastie 1992, Faraway 2006). We used a single term addition model selection (Chambers \& HaSTIE 1992) to evaluate the importance of each variable in discriminating the two sexes: 1) we tested the full model against a constant-only model; 2 ) the significant term with the lowest AIC value was added to the null model; 3) step 2 was repeated; 4) any non-significant terms were dropped from the model; 5) steps 3 and 4 were repeated until no significant terms could be added or no non-significant terms could be dropped from the model. Next, we assessed the misclassification error of the reduced model using 1000 bootstrap replications of a linear discriminant analysis in the package ipred of R v. 3.0.2 (R DeveLopment Core Team 2013). At last, we ranked the importance of each variable using model averaging, retaining only models with $\Delta \mathrm{AIC}_{\mathrm{C}}<4$ (Crawley 2007), using the MuMIn package (Burnham $\&$ Anderson 2002) of R v. 3.0.2 (R Development Core Team 2013).

\section{RESULTS}

All the 170 specimens of $D$. nordestina (120 males and 50 females) analyzed herein were collected in Atlantic Forest areas of Northeastern Brazil (Paraíba and Rio Grande do Norte), and together with literature records confirm the species range, from Rio Grande do Norte State to central and Northern coastal regions of Bahia State (Fig. 2). We recovered data from the literature for 13 localities (Rodrigues et al. 2005, CAMACHO \& Rodrigues 2007, Moura et al. 2010, Delfino \& Soeiro 2012) of occurrence and added to these 15 new localities from our data (Fig. 2).

We analyzed stomach contents of 106 lizards, 18\% of which $(\mathrm{n}=19)$ were empty and $32 \%(\mathrm{n}=34)$ presented unidentifiable (digested) material, plant matter, and sand. We identified 13 prey categories (Table I) and for pooled stomachs the most frequent ones were Formicidae (21.3\%), insect larvae and insect eggs (together 22.5\%). Ants and insect larvae presented high numerical percentages, as did insect eggs: $20.8 \%, 14.0 \%$, and $26.4 \%$, respectively. Volumetrically, Chilopoda (25.4\%), insect larvae (19.3\%), and Dermaptera (16.1\%) were the most representative prey (Table I). By considering the relative importance indexes, Formicidae and insect larvae showed the highest values of IIS (21.38 and 17.89, respectively) and IPS (16.2 and 16.5, respectively, Table I).

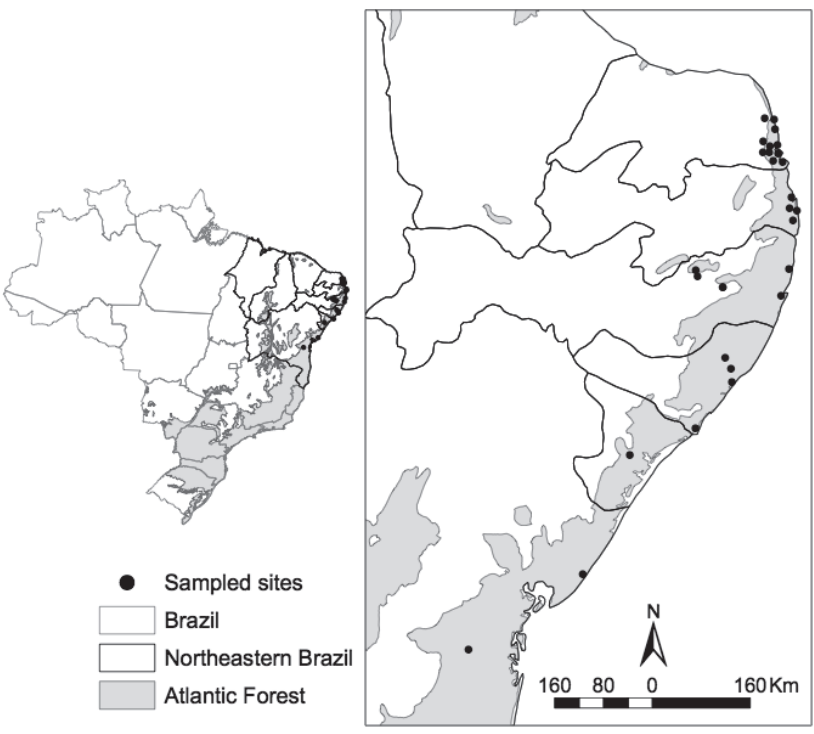

Figure 2. Geographic distribution of Dryadosaura nordestina in Northeastern Brazil based on known records from the literature and results from the present study.

We dissected 157 animals (114 males and 43 females) and found 18 reproductive females $(42 \%$,) two in stage III and 16 in stage II) and 25 were not reproductive (58\%, 18 adults and 7 juveniles). For males, 95 (85\%) were reproductive and 19 (17\%) were juveniles. We were unable to determine the sex of two individuals, which were left out of the subsequent analyses. The smallest reproductive female measured $40.3 \mathrm{~mm}$ in SVL and was ranked as stage II, with well-developed follicles and oviducts. The smallest reproductive male measured $31.2 \mathrm{~mm}$.

Dryadosaura nordestina presents a fixed clutch size of two, and eggs in the oviduct of the two stage III females found $(n=4$ eggs) were of $9.8 \pm 5.9 \mathrm{~mm}$ in length and $4.2 \pm 0.05 \mathrm{~mm}$ in width. Reproductive females appear first in February, but were more common from May to July (Fig. 3). A few juveniles were observed in May and July, but were more abundant from September to November, suggesting that reproduction may be occurring from the end of the dry season to the end of the rainy season (December to February) and hatching in July-August (Fig. 4).

We measured a total of 119 males and 50 females for the morphometric comparisons (Table II). Males are significantly larger than females $\left(\mathrm{F}_{1,147}=20.69, \mathrm{p}<0.001\right.$; mean body sizes: females $=2.42 \pm 0.21$ and males $=2.58 \pm 0.18)$. There are also differences between females and males regarding body shape $\left(\chi^{2}=58.761, \mathrm{p}<0.001\right)$ : model selection procedures pointed to snout-vent length, head height, body width, body height, and head width as the most important variables, correspondingly, for morphometric distinction of genders (Table III). Females are proportionally longer and have wider and higher bodies, while bulkier heads characterize males. 
Table I. Diet composition of Dryadosaura nordestina $(\mathrm{N}=106)$ from states of Rio Grande do Norte and Paraíba, Brazil. ( $\mathrm{n}$ ) Prey number, (v) prey volume, (f) number of stomachs containing prey item, (iis) importance index based on individual stomachs, (ips) importance index based on pooled stomachs.

\begin{tabular}{|c|c|c|c|c|c|c|c|c|c|c|c|c|}
\hline \multirow{2}{*}{ Category } & \multirow{2}{*}{$f$} & \multicolumn{5}{|c|}{ Pooled stomachs } & \multirow{2}{*}{ ips } & \multicolumn{4}{|c|}{ individual stomachs } & \multirow{2}{*}{ iis } \\
\hline & & f\% & $\mathrm{n}$ & $\mathrm{n} \%$ & v & v\% & & $\mathrm{n}$ & $\mathrm{n} \%$ & $\mathrm{v}$ & v\% & \\
\hline Araneae & 6 & 7.50 & 7 & 3.93 & 140.17 & 9.13 & 6.85 & 0.14 & 4.36 & 2.75 & 4.51 & 4.44 \\
\hline Chilopoda & 4 & 5.00 & 6 & 3.37 & 389.46 & 25.37 & 11.25 & 0.12 & 5.10 & 7.64 & 7.01 & 6.05 \\
\hline Coleoptera & 5 & 6.25 & 5 & 2.81 & 68.36 & 4.45 & 4.50 & 0.10 & 8.50 & 1.34 & 8.82 & 8.66 \\
\hline Dermaptera & 4 & 5.00 & 6 & 3.37 & 246.84 & 16.08 & 8.15 & 0.12 & 6.86 & 4.84 & 6.74 & 6.80 \\
\hline Gastropoda & 1 & 1.25 & 1 & 0.56 & 1.09 & 0.07 & 0.63 & 0.02 & 0.10 & 0.02 & 0.04 & 0.07 \\
\hline Hemiptera & 2 & 2.50 & 2 & 1.12 & 11.54 & 0.75 & 1.46 & 0.04 & 2.94 & 0.23 & 2.02 & 2.48 \\
\hline Isopoda & 7 & 8.75 & 12 & 6.74 & 132.73 & 8.64 & 8.05 & 0.24 & 8.71 & 2.60 & 11.31 & 10.01 \\
\hline Isoptera & 9 & 11.25 & 22 & 12.36 & 56.03 & 3.65 & 9.09 & 0.43 & 12.43 & 1.10 & 11.39 & 11.91 \\
\hline Insect Larvae & 13 & 16.25 & 25 & 14.04 & 296.50 & 19.31 & 16.54 & 0.49 & 16.94 & 5.81 & 18.84 & 17.89 \\
\hline Insect parts & 5 & 6.25 & 6 & 3.37 & 77.23 & 5.03 & 4.88 & 0.12 & 5.18 & 1.51 & 4.68 & 4.93 \\
\hline Worms & 2 & 2.50 & 2 & 1.12 & 0.73 & 0.05 & 1.22 & 0.04 & 2.61 & 0.01 & 2.02 & 2.32 \\
\hline
\end{tabular}

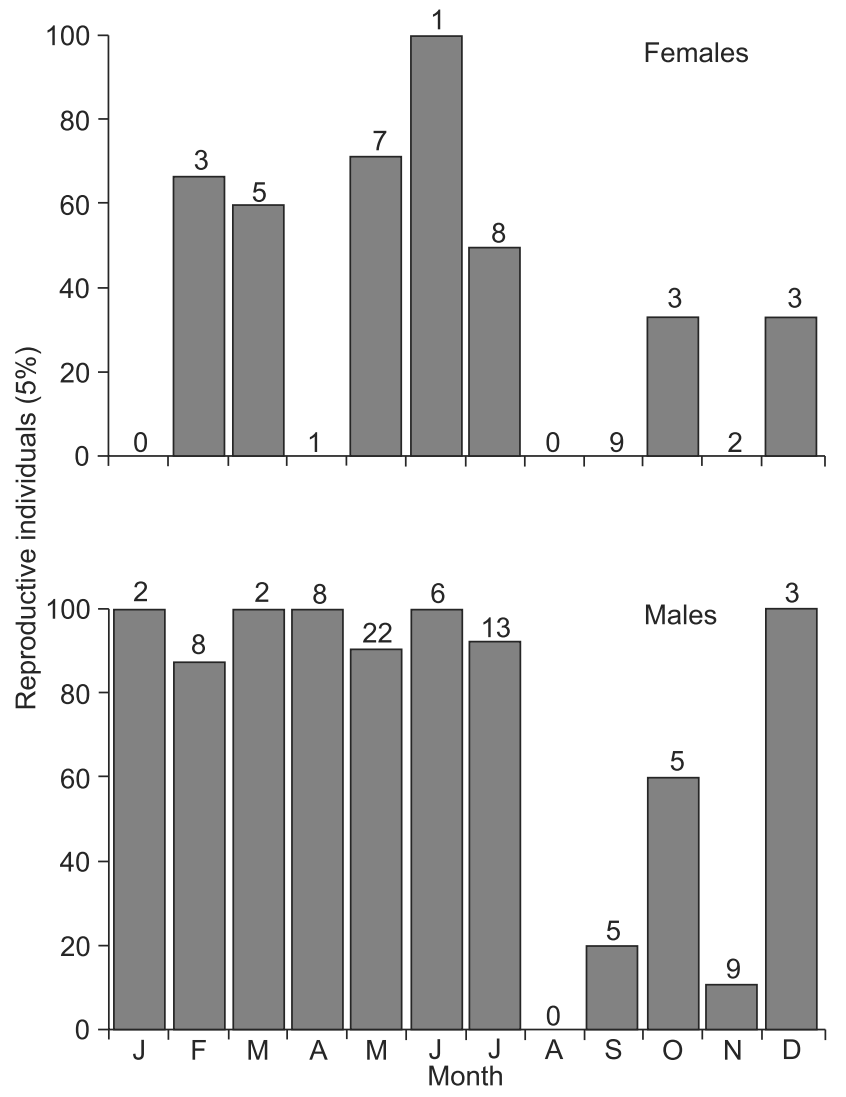

Figure 3. Monthly proportion of reproductive Dryadosaura nordestina collected in Atlantic Forest fragments in Paraíba and Rio Grande do Norte States, Brazil. Total number of specimens available per month is indicated over each bar.

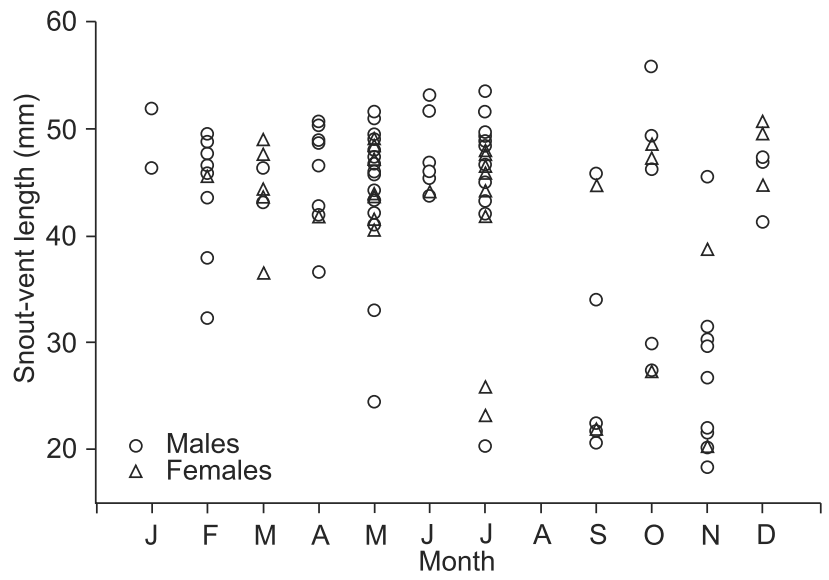

Figure 4. Monthly distribution of snout-vent lengths per month of male and female of Dryadosaura nordestina collected in Atlantic Forest fragments in Paraíba and Rio Grande do Norte States, Brazil.

Table II. Average morphometric measurements for male and female Dryadosaura nordestina. Values represent mean \pm standard deviation of isometric body size and shape (size-free) variables. Raw values $(\mathrm{mm})$ are in brackets.

\begin{tabular}{lcc}
\hline \multicolumn{1}{c}{ Variables } & Males & Females \\
\hline Body size & $2.56 \pm 0.18$ & $2.42 \pm 0.21$ \\
Snout-vent length & $0.74 \pm 0.021(45.4 \pm 5.7)$ & $0.77 \pm 0.031(42.7 \pm 7.1)$ \\
Body height & $-0.24 \pm 0.065(4.8 \pm 1.0)$ & $-0.22 \pm 0.060(4.5 \pm 1.0)$ \\
Body width & $-0.8 \pm 0.032(6.8 \pm 1.1)$ & $-0.7 \pm 0.038(6.3 \pm 1.2)$ \\
Head width & $-0.14 \pm 0.025(6.2 \pm 0.9)$ & $-0.12 \pm 0.029(5.2 \pm 0.7)$ \\
Head height & $-0.29 \pm 0.09(4.3 \pm 0.7)$ & $-0.31 \pm 0.031(3.5 \pm 0.6)$ \\
Head length & $-0.16 \pm 0.067(5.8 \pm 1.2)$ & $-0.17 \pm 0.051(5.0 \pm 1.0)$ \\
Forelimb length & $-0.057 \pm 0.043(7.2 \pm 1.2)$ & $-0.067 \pm 0.035(6.2 \pm 1.0)$ \\
Hindlimb length & $0.02 \pm 0.03(13.0 \pm 1.7)$ & $0.021 \pm 0.044(11.9 \pm 2.1)$ \\
\hline
\end{tabular}


Table III. Model selection and model averaging of shape variables as predictors of sex in Dryadosaura nordestina. The best model is the shortest based on the manual selection of variables and the Akaike's Information Criterion (AIC). The values for $\chi^{2}$ represent the differences among the full and best models compared to the null model, and $\mathrm{p}$ the significance of this difference. For each variable, coefficients are presented for each respective model. Asterisks indicate significant model-averaged coefficients $(\mathrm{p}<0.05)$. (svl) Snout-vent length, (bw) body width, (bh) body height, (hw) head width, (hh) head height, (hl) head length, (fll) forelimb length, (hIl) hindlimb length.

\begin{tabular}{|c|c|c|c|c|c|c|c|c|c|c|c|c|}
\hline & Intercept & svl & bw & bh & hw & $\mathrm{hh}$ & hl & fll & hll & AIC & $x^{2}$ & $p$ \\
\hline Full model & 38.48 & -47.23 & -16.84 & -15.63 & 15.70 & 17.89 & -4.46 & 0.52 & - & 138.71 & 116.26 & $<0.0001$ \\
\hline Best model & 38.13 & -43.85 & -14.04 & -13.30 & 17.44 & 19.59 & - & - & - & 135.48 & 114.72 & $<0.0001$ \\
\hline Model-averaged coefficients & $38.27^{*}$ & $-45.56^{*}$ & -14.81 & -13.75 & 22.07 & 24.09 & -0.30 & 6.60 & 6.37 & - & - & - \\
\hline Relative Importance & - & 0.95 & 0.76 & 0.87 & 0.80 & 0.88 & 0.54 & 0.50 & 0.44 & - & - & - \\
\hline
\end{tabular}

\section{DISCUSSION}

Dryadosaura nordestina is found in the northeastern portion of the Brazilian Atlantic Forest, from Rio Grande do Norte state to northeastern costal Bahia state (Rodrigues et al. 2005, Camacho \& Rodrigues 2007, Delfino \& Soeiro 2012, de Oliveira $\&$ Pessanha 2013). Our data confirms the geographic pattern suggested for the species in its description (Rodrigues et al. 2005) and provides a considerable increase in known localities for the species. A recent study on the herpetofauna richness and abundance of Atlantic Forest fragments in Rio Grande do Norte state showed that $D$. nordestina is the most abundant lizard species (Lion et al. 2014). Nevertheless, most sites where specimens were collected are relatively recent small forest fragments, which are known to suffer from forest edge effects and local microhabitat change involved in lizard declines worldwide (Sinervo et al. 2010). Hence, although widely distributed and abundant, the species conservation status requires adequate monitoring to evaluate population trends in these small fragments within a highly fragmented landscape.

Based on dietary data available, Gymnophthalmid lizards are known to be active foragers (RосHA 1994). For example, SANTOs et al. (2012) showed that Nothobachia ablephara Rodrigues, 1984 feeds mostly on sedentary or gregarious prey (e.g., termites and insect larvae), which are usually obtained by active foragers. Similarly, D. nordestina ingests insect larvae, termites, and gastropods, prey items habitually consumed by active foragers. The species furthermore presents a generalist behavior, given that no prey item was significantly more important than others, although a slight preference for ants and insect larvae and eggs is evident (Table I).

Some studies have demonstrated that ants and insect larvae are of major relevance for gymnophthalmids diets. U.G. Silva (unpubl. data) reported on the diet of D. nordestina, identifying Formicidae and Coleoptera as the most important items, but also reporting on Isoptera, Hemiptera, Coleoptera, Formicidae, and Isopoda. Our data adds Gastropoda, Dermaptera, Chilopoda, Araneae, and insect egg and larvae as part of the species diet. Bachia bresslaui (Amaral, 1935) (Colli et al. 1998), Proctoporus species (DoAn 2008), N. ablephara (SANTOs et al. 2012), Anotosaura vanzolinia Dixon, 1974 (de Oliveira \& Pessanha 2013),
Potamites ecpleopus (Cope, 1876) and Potamites juruazensis (ÁvilaPires \& Vitt, 1998) (VitT \& Ávila-Pires 1998), although presenting ants and insect larvae in their diets, do not show volumetric importance for those prey categories (VITT \& Ávila-PiRes 1998). Likewise, D. nordestina also presents a not volumetrically important high number of ants but indeed a relatively notable volumetric importance of insect larvae.

Despite their abundance in tropical ecosystems, ants are a relatively underutilized resource by lizards (Sites et al. 2011). The consumption of these toxic, low energy preys was previously considered ancestral in Squamates (VitT \& Pianka 2005), but recent phylogenic hypotheses, with Iguania appearing at the tip of the tree rather than as part of a basal split, challenged this view (SITEs et al. 2011). Within gymnophthalmids, ant consumption is not a rule, but these prey have been shown to be important for several species in the family, although never dominant (DoAn 2008). Eating ants is usually a characteristic of Tropidurid lizards and may be energetically ineffective because ants are relatively small and have a proportionally thick cuticle, with an associated metabolic cost for toxin processing (VITT et al. 2008). Conversely, eating ants may be advantageous by compensating for the costs related to browsing for nontoxic and larger prey categories, because ants are generally encountered in agglomerations (VitT \& CALDwell 2009). The appreciable importance of ants on D. nordestina raises two not necessarily mutually exclusive hypotheses about its natural history: (I) the lizard presents an intermediary foraging strategy concerning sit-and-wait and active foragers and/or (II) ants are abundant enough to increase the probability of encounters between prey and predator.

Lizard dietary shifts are probably related to evolutionary divergences on behavior and morphology among clades (VITT et al. 2007a). By comparing our results with several similar works with gymnophthalmid lizards we can argue for some degree of historical conservatism, at least regarding D. nordestina and Ptychoglossus bicolor (Werner, 1916) (ANaYa-Rojas et al. 2010), Micrablepharus maximilianii (Reinhardt \& Lütken, 1862), and Vanzosaura rubricauda (Boulenger, 1902) (D.C.P.S. Aquino, unpubl. data), Leposoma scincoides (TeIXeIRA \& Fonseca 2003), Cercosaura eigenmannii (Griffin, 1917) (Viтt et al. 1998), Alopoglossus angulatus (Linnaeus, 1758) and A. atriventis 
Duellman, 1973 (VITt et al. 2007a), P. ecpleopus, P. juruazensis (Vitt \& Ávila-Pires 1998) and A. vanzolinia (De Oliveira \& Pessanha 2013). Regarding diet, the most similar species to $D$. nordestina is A. vanzolinia, it's sister species. Both feed mainly on Formicidae, invertebrate eggs, and Isoptera (DE OliveIRA \& Pessanha 2013), what supports a phylogenetic influence on the diet of D. nordestina (and probably within Gymnophthalmidae).

Dryadosaura nordestina presents, like other gymnophthalmids (Fiтch 1970), a fixed clutch size of two eggs. Fixed clutch sizes may constrain individuals to produce larger eggs and multiple clutches per reproductive season (TinkLe et al. 1970), leading females to produce clutches in a fast, consecutive, and continuous fashion (ANDREws \& Rand 1974, VitT 1986, Doughty 1997, Pianka \& VitT 2003). Indeed, most reproduction of $D$. nordestina occurs from May to June (when most reproductive females and the only gravid ones were found), with most juveniles emerging subsequently from July through November. Hence, although clutch size is fixed, most reproductive females are found during the rainy season, and juveniles emerge from the beginning to the middle of the dry season. Still, reproductive females containing developed follicles are found almost year round, as well as juveniles, which is an evidence of prolonged reproduction, and even though we did not find evidences for multiple clutches per female, it seems that more than one reproductive event could occur, and reproduction of $D$. nordestina does not appear totally seasonal, which is in agreement with the aforementioned constraint. Ptychoglossus bicolor does not reproduce seasonally as well (RAmos-PaLlares et al. 2010), but additional studies are necessary to propose a pattern.

Sexual dimorphism can has many causes, such as female advantage due to the production of bigger clutches ( 1981, Stamps 1983, Carothers 1984 , Anderson \& Vitt 1990) to asymmetrical investment in reproduction among sexes (FIтcH 1981, VAN SLuYs 1998). Furthermore, males with bigger heads may be sexually selected in intrasexual competition for females (Vitt \& Cooper 1985, Anderson \& VitT 1990). Additionally, sexual dimorphism can reduce intraspecific competition for food (VAn Sluys 1993, Perry 1996). Although it is often hard to access the precise reason for sexual size dimorphism in a given species, intrasexual selection seems a plausible cause for larger males in teiid species (Anderson \& VitT 1990), and it may also be the cause for $D$. nordestina and other gymnophthalmids. Nevertheless, even though clutch size is fixed in gymnophthalmids, longer and wider bodies in females can accommodate larger eggs and thus favor selection on such morphometric variables.

Larger males are also characteristic of $P$. bicolor (RAmosPallares et al. 2010) and Alexandresaurus camacan (Rodrigues et al. 2007), which may be indicative of intrasexual conflict to access females. Likewise, head shape has been repeatedly reported as a sexually dimorphic character in other gymnophthalmids (VITT 1982). Our model selection procedure identified snout-vent length, and both head and body height and width as the most discriminatory variables for gender differentiation. ANDERSON \& VITT (1990) suggested that head shape is directly related to facilitate mating because males can hold females tightly, besides providing advantages in male-male combat. Males with larger heads (than females) are also found in Cercosaura schreibersii Wiegmann, 1834 (BALESTRIN et al. 2010) and V. rubricauda (D.C.P.S. Aquino, unpubl. data).

\section{ACKNOWLEDGEMENTS}

We thank ICMBio and REBIO Guaribas for collecting permits and all our peers at Laboratório de Anfíbios e Répteis, UFRN for support during fieldwork. DOM thanks the University of Texas and Eric Pianka for providing to conditions to finalise this manuscript. Two anonymous reviewers made valuable suggestions that significantly improved the quality of this manuscript. This work was supported by grants from Fundação Boticário de Proteção à Natureza, CEPAN, and FAPERN awarded to AAG, and from FAPESQ/CNPq Programa de Infra-Estrutura para Jovens Pesquisadores and CNPq/Universal 2009 to DOM.

\section{LITERATURE CITED}

Anaya-Rojas, J.M.; V.H. Cardozo-Serrano \& M.P. Ramírez-Pinilla. 2010. Diet, microhabitat use, and thermal preferences of Ptychoglossus bicolor (Squamata: Gymnophthalmidae) in an organic coffee shade plantation in Colombia. Papéis Avulsos de Zoologia (São Paulo) 50: 159-166. doi: 10.1590/ S0031-10492010001000001

Anderson, R.A. \& L.J. Vitt. 1990. Sexual selection versus alternative causes of sexual dimorphism in Teiid lizards. Oecologia 84: 145-157. doi: 10.1007/BF00318265

AndRews, R. \& A.S. Rand. 1974. Reproductive effort in anoline lizards. Ecology 55: 1317-1327. doi: 10.2307/1935459

Balestrin, R.L.; L.H. Cappellari \& A.B. Outeiral. 2010. Reproductive biology of Cercosaura schreibersii (Squamata, Gymnophthalmidae) and Cnemidophorus lacertoides (Squamata, Teiidae) in Sul-Riograndense Shield, Brazil. Biota Neotropica 10: 131139. doi: 10.1590/S1676-06032010000100013

Barros, F.C.; A. Herrel \& T. Kohlsdorf. 2011. Head shape evolution in Gymnophthalmidae: does habitat use constrain the evolution of cranial design in fossorial lizards? Journal of Evolutionary Biology 24: 2423-2433. doi: 10.1111/ j.1420-9101.2011.02372.x

Burnaby, T.P. 1966. Growth-invariant discriminant functions and generalized distances. Biometrics 22: 96-110. doi: $10.2307 / 2528217$

Burnham, K.P. \& D.R. Anderson. 2002. Model Selection and Multimodel Inference: A Practical Information-Theoretic Approach. New York, Springer, 514p.

Camacho, A.G. \& M.T. Rodrigues. 2007. Dryadosaura nordestina (Squamata, Gymnophthalmidae): Geographic distribution. Herpetological Review 38: 218-219. 
Carothers, J.H. 1984. Sexual selection and sexual dimorphism in some herbivorous lizards. American Naturalist 124: 244254. doi: $10.1086 / 284266$

Castoe, T.A.; T.M. Doan \& C.L. Parkinson. 2004. Data partitions and complex models in Bayesian analysis: The phylogeny of Gymnophthalmid lizards. Systematic Biology 53: 448469. doi: 10.1080/10635150490445797

Chambers, J.M. \& T.J. Hastie. 1992. Statistical Models in S. Pacific Grove, Wadsworth \& Brooks, Cole Advanced Books \& Software, 608p.

Colli, G.R.; M.G. Zatz \& H.J. DA CunHa. 1998. Notes on the ecology and geographical distribution of the rare gymnophthalmid lizard Bachia bresslaui. Herpetologica 54: 169-174. Available online at: http://www.jstor.org/stable/3893424 [Accessed: 13/ $\mathrm{X} / 2014]$

Crawley, M.J. 2007. The R Book. West Sussex, John Wiley \& Sons, 942p.

de Oliveira, B.H.S. \& A.L.M. Pessanha. 2013. Microhabitat use and diet of Anotosaura vanzolinia (Squamata: Gymnophthalmidae) in a Caatinga area, Brazil. Biota Neotropica 13: 193-198. doi: 10.1590/S1676-06032013000300022

Delfino, M.S.C. \& M.S. SoEIro. 2012. Dryadosaura Nordestina (Briba cabeçuda). Brazil, Bahia. Herpetological Review 43: 102.

DoAn, T.M. 2008. Dietary variation within the Andean lizard clade Proctoporus (Squamata: Gymnophthalmidae). Journal of Herpetology 42: 16-21. doi: 10.1670/06-037.1

Doughty, P. 1997. The effects of "fixed" clutch sizes on lizards life-histories: reproduction in the Australian velvet gecko, Oedura lesueurii. Journal of Herpetology 31: 266-272. doi: $10.2307 / 1565395$

Dunham, A.E.; D.B. Miles \& D.N. Reznick. 1988. Life history patterns in squamate reptiles; p. 441-522. In: C. Gans \& R.B. HuEy (Eds). Biology of The Reptilia. New York, Alan R. Liss, vol. 16.

Faraway, J.J. 2006. Extending the Linear Model with R: Generalized Linear, Mixed Effects and Nonparametric Regression Models. Boca Raton, Chapman \& Hall/CRC, Florida, 301p.

Filzmoser, P.; R.G. GarRetT \& C. ReimanN. 2005. Multivariate outlier detection in exploration geochemistry. Computers \& Geosciences 31: 579-587. doi: 10.1016/j.cageo.2004.11.013

FiтcH, H.S. 1970. Reproductive cycles in lizards and snakes. Miscellaneous Publications of the Natural History Museum, University of Kansas 52: 1-247.

Fiтch, H.S. 1981. Sexual size differences in reptiles. Miscellaneous Publications of the Museum of Natural History, University of Kansas 70: 1-72.

Grizante, M.B.; R. BRANDT \& T. KoHLSDORF. 2012. Evolution of body elongation in gymnophthalmid lizards: relationships with climate. Plos One 7: e49772. doi: 10.1371/journal.pone.0049772

Jolicoeur, P. 1963. The multivariate generalization of the allometry equation. Biometrics 19: 497-499. doi: 10.2307/ 2527939
LION, M.B.; A.A. GARDA \& C.R. FonseCA. 2014. Split distance: a key landscape metric shaping amphibian populations and communities in forest fragments. Diversity and Distributions 20: $1245-1257$. doi: $10.1111 /$ ddi. 12228

Losos, J.B. 2009. Lizards In An Evolutionary Tree: Ecology And Adaptive Radiation Of Anoles. Berkeley, University of California Press, 507p.

Losos, J.B.; D.M. Hiluis \& H.W. Greene. 2012. Who speaks with a forked tongue? Science 338: 1428-1429. doi: 10.1126/ science. 1232455

Moura, G.J.B.; E.M. dos Santos; M.A.B. de Oliveira \& M.C.C. Cabral. 2010. Herpetofauna no Estado de Pernambuco. Brasília, Instituto Brasileiro do Meio Ambiente e dos Recursos Naturais Renováveis, 441p.

Pellegrino, K.; M.T. Rodrigues; Y. Yonenaga-Yassuda \& J.W. Sites. 2001. A molecular perspective on the evolution of microteiid lizards (Squamata, Gymnophthalmidae), and a new classification for the family. Biological Journal of the Linnean Society 74: 315-338. doi: 10.1006/bijl.2001.0580

Perry, G. 1996. The evolution of sexual dimorphism in the lizard Anolis polylepis (Iguania): Evidence from intraspecific variation in foraging behavior and diet. Canadian Journal of Zoology 74: 1238-1245. doi: 10.1139/Z96-137

PiANKA, E.R. \& L.J. VitT. 2003. Lizards: Windows to the Evolution of Diversity. Berkeley, University of California Press.

Pyron, R.A. \& F.T. Burbrink. 2014. Early origin of viviparity and multiple reversions to oviparity in squamate reptiles. Ecology Letters 17: 13-21. doi: 10.1111/Ele.12168

R Development Core Team. 2013. R: A language and environment for statistical computing. Vienna, R Foundation for Statistical Computing. Available online at: http://www.R-project.org

Ramos-Pallares, E.; V.H. Serrano-Cardozo \& M.P. Ramírez-Pinilla. 2010. Reproduction of Ptychoglossus bicolor (Squamata: Gymnophthalmidae) in an Andean Coffee dhade plantation in Colombia. South American Journal of Herpetology 5: 143-150. doi: 10.2994/057.005.0208

Rосна, C.F.D. 1994. A ecologia de lagartos no Brasil: status e perspectivas, p. 35-57. In: L.B. NASCIMENTO; A.T. Bernardes \& G.A. CоттA (Eds). Herpetologia no Brasil. Belo Horizonte, PUCMG, Fundação Biodiversitas, Fundação Ezequiel Dias.

Rodrigues, M.T.; E.M.X. Freire; K.C.M. Pellegrino \& J.W. Sites. 2005. Phylogenetic relationships of a new genus and species of microteiid lizard from the Atlantic forest of north-eastern Brazil (Squamata, Gymnophthalmidae). Zoological Journal of the Linnean Society 144: 543-557. doi: 10.1111/j.10963642.2005.00177.x

Rodrigues, M.T.; H.C.M. Pellegrino; M. Dixo; V.K. Verdade; D. Pavan; A.J.S. Argolo \& J.W. Sites. 2007. A new genus of microteiid lizard from the Atlantic forests of state of Bahia, Brazil, with a new generic name for Colobosaura mentalis, and a discussion of relationships among the Heterodactylini (Squamata, Gymnophthalmidae). American Museum Novitates: 1-27. doi: 10.1206/0003-0082 
RohlF, F.J. \& F.L. Bookstein. 1987. A comment on shearing as a method for size correction. Systematic Zoology 36: 356367. doi: http://www.jstor.org/stable/2413400

Santos, M.V.G.; I.G.S. Macedo; R.S. De Sousa; M. Gogliath \& L.B. Ribeiro. 2012. Diet of Nothobachia ablephara (Squamata: Gymnophthalmidae) in a Caatinga area of the San Francisco Valley in northeastern Brazil. Herpetology Notes 5: 305307.

Sinervo, B.; F. Mendez-de-la-Cruz; D.B. Miles; B. Heulin; E. Bastiaans; M.V.S. Cruz; R. Lara-Resendiz; N. Martinez-Mendez; M.L. Calderon-Espinosa; R.N. Meza-Lazaro; H. Gadsden; L.J. Ávila; M. Morando; I.J. De la Riva; P.V. Sepulveda; C.F.D. Rocha; N. Ibarguengoytia; C.A. Puntriano; M. Massot; V. Lepetz; T.A. Oksanen; D.G. Chapple; A.M. Bauer; W.R. Branch; J. Clobert \& J.W. Sites. 2010. Erosion of lizard diversity by climate change and altered thermal niches. Science 328: 894-899. doi: 10.1126/Science.1184695

Sites, J.W.; T.W. Reeder \& J.J. Wiens. 2011. Phylogenetic insights on evolutionary novelties in lizards and snakes: sex, birth, bodies, niches, and venom. Annual Review of Ecology, Evolution, and Systematics 42: 227-244. doi: 10.1146/ Annurev-Ecolsys-102710-145051

SOMERS, K.M. 1986. Multivariate allometry and removal of size with principal components analysis. Systematic Zoology 35: 359-368. doi: 10.2307/2413387

StAmps, J.A. 1983. Sexual selection, sexual dimorphism, and territoriality I; p. 169-204. In: R.B. Huey; E.R. PianKa \& T.W. Schoener (Eds). Lizard ecology. Studies of a model organism. Cambridge, Harvard University Press.

Stearns, S.C. 1992. The Evolution of Life Histories. Oxford, Oxford University Press, 262p.

TаваснNicк, B.G. \& L.S. Fidell. 2001. Using Multivariate Statistics. Needham Heights, Allyn and Bacon, 966p.

Teixeira, R.L. \& F.R. Fonseca. 2003. Tópicos ecológicos de Leposoma scincoides (Sauria, Gymnophthalmidae) da região de Mata Atlântica de Santa Teresa, Espírito Santo, sudeste do Brasil. Boletim do Museu de Biologia Mello Leitão 15: 17-28.

Tinkle, D.W.; H.M. Wilbur \& S.G. Tilley. 1970. Evolutionary strategies in lizard reproduction. Evolution 24: 55-74. doi: $10.2307 / 2406714$

VAN SLUYS, M. 1993. The reproductive cycle of Tropidurus itambere (Sauria, Tropiduridae) in southeastern Brazil. Journal of Herpetology 27: 28-32. doi: 10.2307/1564901

VAN SLuYs, M. 1998. Growth and body condition of the saxicolous lizard Tropidurus itambere in southeastern Brazil. Journal of Herpetology 32: 359-365. doi: 10.2307/1565450
VitT, L.J. 1982. Sexual dimorphism an reproduction in the microteiid lizard, Gymnophthalmus multiscutatus. Journal of Herpetology 16: 325-329. doi: 10.2307/1563730

VITT, L.J. 1986. Reproductive tactics of sympatric gekkonid lizards with a comment on the evolutionary and ecological consequences of invariant clutch size. Copeia 3: 773-786. doi: $10.2307 / 1444960$

VITT, L.J. 2013. Walking the natural-history trail. Herpetologica 69: 105-117. doi: 10.1655/herpetologica-d-13-00027

VITT, L.J. \& T.C.S. ÁviLA-Pires. 1998. Ecology of two sympatric species of Neusticurus (Sauria: Gymnophthalmidae) in the Western Amazon of Brazil. Copeia 1998: 570-582. doi: 10.2307/1447787

VitT, L.J. \& J.P. CALDWELL. 2009. Herpetology: An Introductory Biology of Amphibians and Reptiles. Academic Press, San Francisco, 697p.

VITT, L.J. \& J.P. CALDWELL. 2013. Herpetology: An Introductory Biology of Amphibians and Reptiles. San Diego, Academic Press, $4^{\text {th }}$ ed., 776p.

VITT, L.J. \& J.D. Congdon. 1978. Body shape, reproductive effort, and relative clutch mass in lizards: resolution of a paradox. American Naturalist 112: 595-608. Available online at: http://www.jstor.org/stable/2460126 [Accessed: 13/X/2014]

VitT, L.J. \& W.E. Cooper. 1985. The evolution of sexual dimorphism in the skink Eumeces laticeps: an example of sexual selection. Canadian Journal of Zoology 63: 9951002. doi: $10.1139 / \mathrm{z} 85-148$

VitT, L.J. \& E.R. PianKa. 2005. Deep history impacts present-day ecology and biodiversity. Proceedings of the National Academy of Sciences of the United States of America 102: 7877-7881. doi: 10.1073/pnas.0501104102

Vitt, L.J.; B. Magnusson; T.C.S. Ávila-Pires \& A.P. Lima. 2008. Guide to the Lizards of Adolpho Ducke-Central Amazonia. Manaus, Áttema Design Editorial, 175p.

VitT, L.J.; S.S. Sartorius; T.C.S. Ávila-Pires \& M.C. Esposito. 1998. Use of time, space, and food by the gymnophthalmid lizard Prionodactylus eigenmanni from the western Amazon of Brazil. Canadian Journal of Zoology 76: 1681-1688. doi: 10.1139/ Cjz-76-9-1681

VitT, L.J.; T.C.S. Ávila-Pires; M.C. Espósito; S.S. Sartorius \& P.A. ZANi. 2007a. Ecology of Alopoglossus angulatus and $A$. atriventris (squamata, gymnophthalmidae) in western Amazonia. Phyllomedusa 6: 11-21. doi: 10.11606/issn.23169079.v6i1p11-21

Vitt, L.J.; D.B. Shepard; J.P. Caldwell; G.H.C. Vieira; F.G.R. FranÇA \& G.R. Colli. 2007b. Living with your food: geckos in termitaria of Cantão. Journal of Zoology 272: 321-328. doi: 10.1111/j.1469-7998.2006.00273.x

Submitted: 26.V.2014; Accepted: 07.IX.2014.

Editorial responsibility: Diego Astúa de Moraes 